ENTREPRENEURSHIP AND SUSTAINABILITY ISSUES

ISSN 2345-0282 (online) http://jssidoi.org/jesi/

2020 Volume 7 Number 3 (March)

http://doi.org/10.9770/jesi.2020.7.3(51)
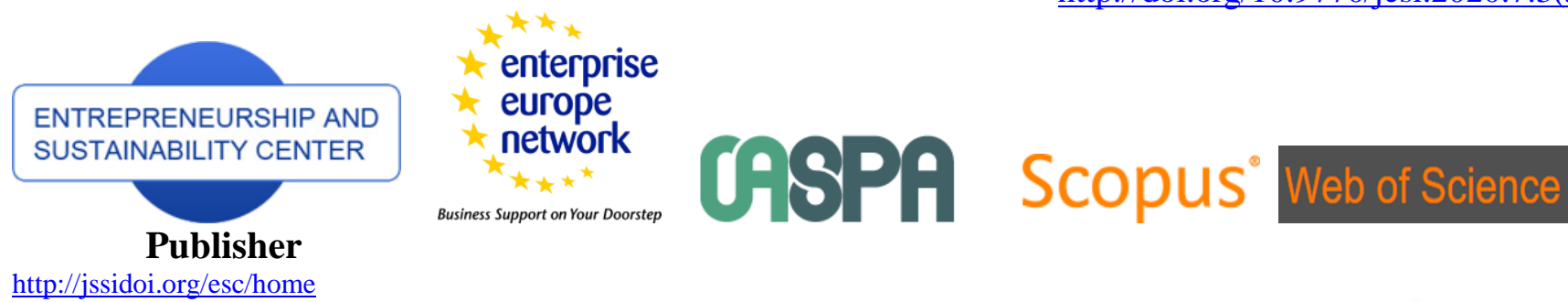

http://jssidoi.org/esc/home

Business Support on Your Doorstep

1) Clarivate Analytics

\title{
LABOR OPPORTUNISM AS A BLOCKING FACTOR FOR THE INNOVATIVE DEVELOPMENT OF INDUSTRIAL ENTERPRISES
}

\author{
Irina I. Frolova ${ }^{1 *}$, Vladimir V. Nosov ${ }^{2}$, Nadezhda B. Zavyalova ${ }^{3}$, Aleksei E. Dorofeev ${ }^{4}$, \\ Tatiana M. Vorozheykina ${ }^{5}$, Lyudmila I. Petrova ${ }^{6}$ \\ ${ }^{1}$ Kazan Innovative University named after V.G. Timiryasov, Moskovskaya st., 42, Kazan, Russian Federation \\ ${ }^{2}$ K.G. Razumovsky Moscow State University of technologies and management (the First Cossack University) \\ (RAZUMOVSKY MSUTM (FCU)), 109004, st. Ground Val, 73, Moscow, Russian Federation \\ Academy of the Investigative Committee of the Russian Federation, Moscow, Russian Federation \\ ${ }^{3}$ Plekhanov Russian University of Economics, Stremyanny lane, 36, Moscow, 117997, Russian Federation \\ ${ }^{4}$ I.M. Sechenov First Moscow State Medical University of the Ministry of Health of the Russia, Trubetskaya st., 8/2, \\ Moscow, Russian Federation \\ ${ }^{5}$ Financial University under the Government of the Russian Federation, Leningradsky Prospekt, 49, 125993, Moscow, \\ Russian Federation \\ ${ }^{6}$ Altai state University, Lenina Str. 61, Barnaul, Russian Federation \\ E-mail:*1 fii@mail.ru (Corresponding author)
}

Received 20 August 2019; accepted 20 January 2020; published 30 March 2020

\begin{abstract}
The innovative way of enterprise development depends on many issues in the framework of legislation, financing, infrastructure, human resources, technological base, information, and other areas. The current study analyzes the factors that determine the manifestations of labor opportunism and its forms based on functional and resource approaches, taking into account institutional and economic constraints among workers in the energy industry. The results of a sociological study on the forms of opportunistic behavior at the enterprises of the energy industry are presented. The results of the study indicate that labor opportunism is one of the significant factors that block the innovative development of an enterprise. It has a major impact on labor relations as long as one of the conditions for the emergence of opportunism is a conflict of interests between the employee and the employer. It occurs when the interests of one economic agent run counter to the interests of another. This is proved by the results of assessing the influence of various factors on the opportunism level of employees of energy enterprises and is based on correlation and regression analysis. In the framework of this study, labor opportunism is understood as a form of selfish behavior of an employee pursuing personal gain as a response to a conflict of interests between economic agents in the course of labor activity. The conclusions reached suggest that labor opportunism should be considered as a blocking factor when designing the innovative development of an industrial enterprise. Measures aimed at overcoming labor opportunism, building trust in the team and raising the level of innovation in enterprises are proposed.
\end{abstract}

Keywords: labor opportunism; innovative development; innovative activity; opportunistic behavior

Reference to this paper should be made as follows: Frolova, I.I., Nosov, V.V., Zavyalova, N.B., Dorofeev, A.E., Vorozheykina, T.M., Petrova, L.I. (2020). Labor opportunism as a blocking factor for the innovative development of industrial enterprises. Entrepreneurship and Sustainability Issues, 7(3), 2228-2242. http://doi.org/10.9770/jesi.2020.7.3(51)

JEL Classifications: D73, Q01, E26, E65 


\section{ENTREPRENEURSHIP AND SUSTAINABILITY ISSUES}

ISSN 2345-0282 (online) http://jssidoi.org/jesi/

2020 Volume 7 Number 3 (March)

http://doi.org/10.9770/jesi.2020.7.3(51)

Additional disciplines law, sociology

\section{Introduction}

The relevance of studying labor opportunism is determined by its significance as an economic phenomenon characteristic of any economic system which contains labor relations.

The study of labor opportunism as a negative phenomenon that impedes the innovative development of enterprises is becoming an urgent issue in management practice. Many scientists (Belyaev et al., 2013; Bodrov et al., 2014; Ruff, 2014, 2018; Krasikov and Roshchina, 2018; Adams, 2019; Lane, 2017, Rutten and Oerlemans, 2009; Bernardi, 2019) pay attention to various factors determining the manifestations of labor opportunism and its forms based on functional and resource approaches. The institutional and economic constraints of workers are also taken into account.

Labor opportunism has a serious impact on labor relations since one of the conditions for its emergence is a conflict of interests between the employee and the employer, when the interests of one economic agent run counter to the interests of another. The results of assessing the degree of influence of various factors on the level of labor opportunism of energy enterprises' employees based on correlation and regression analysis show that labor activity is often opportunistic in nature. It blocks the innovative development of enterprises and the exercising of the initiative (Bekebayeva et al., 2019; Strunc, 2019; Shatalova et al., 2015; Lateef et al., 2019; Zeibote et al., 2019; Voronkova et al., 2019; Yemelyanov et al., 2018; Magsumov, 2014, 2017; Anamova and Nartova, 2019).

A pilot case study was conducted by a questionnaire survey in order to determine the level of labor opportunism of employees of industrial enterprises in the energy sector. Five hundred employees aged 18 to 65 years old took part in it, out of which $26.2 \%$ were from 18 to 29 years old; $20.4 \%$ were $30-39$ years old; $28.8 \%$ were $40-49$ years old; $18.4 \%$ were $50-59$ years old, and $6.2 \%$ were over 60 years old. Most of the respondents were men (62.8\%). Additionally, 20 managers of different levels were interviewed. More than half of the managers (65\%) were in the age group over 50 years old, $35 \%$ of managers aged 40 to 49 years.

Object of study: factors that determine the manifestations of labor opportunism and its forms based on functional and resource approaches, taking into account institutional and economic constraints among workers in the energy industry.

The subject of the study is labor opportunism as a factor in blocking the innovative development of enterprises in the energy sector.

Objectives of the study:

1. Conduct a review of scientific research on the issue of labor opportunism.

2. Study the factors that determine the manifestations of labor opportunism and its forms in the energy industry.

3. Analyze and interpret the results of sociological study in order to determine the level of labor opportunism in the energy sector enterprises.

4. Determine the influence of various factors on the level of labor opportunism of employees of energy enterprises based on correlation and regression analysis.

5. Provide conclusions and develop recommendations aimed at leveling the factors of labor opportunism of workers that block the innovative development of enterprises.

The following hypotheses are made:

- labor opportunism is present in any enterprise as a response to the opposition of economic interests of the employee and the employer; 


\section{ENTREPRENEURSHIP AND SUSTAINABILITY ISSUES}

ISSN 2345-0282 (online) http://jssidoi.org/jesi/

2020 Volume 7 Number 3 (March)

http://doi.org/10.9770/jesi.2020.7.3(51)

- various factors that affect the labor opportunism of workers and block the innovative development are identified in the practice of enterprise management;

- workers and managers have a different view of labor opportunism;

- labor opportunism has a serious impact on the innovative efficiency of the enterprise.

According to the study results, $72.4 \%$ of respondents among employees and $85 \%$ of managers noted that employees exhibited opportunistic behavior in the process of working while pursuing their own benefits.

All managers participating in a sociological survey considered labor opportunism a serious threat to the development of the enterprise and to its effective functioning.

The results obtained are of practical importance not only for enterprises of the energy sector but for all industrial enterprises where it is possible to use a scientific-integrative model of anti-opportunistic behavior using managerial mechanisms in the system of social and labor relations of the enterprise, using the model equation obtained by the ordinary least squares (OLS) method.

\section{Literature review}

Innovative efficiency is considered in scientific studies (Arvanitis et al., 2008; Bae and Chang 2012; Lazzarotti et al. 2012; Meissner and Carayannis 2017; Tvaronavičienė, 2017; Hou et al. 2019; Omarova et al., 2018; Radicic et al. 2019; Akhmetshin, 2017; Pavlyshyn et al., 2019; Tarman and Dev, 2018; Saenko et al., 2019; Prodani et al., 2019; El Iysaouy et al, 2019) as a competitive advantage of enterprises that can support their sustainable development. It depends on many factors of both external (legislation, external knowledge, etc.) and internal environment of the company (personnel, information, equipment, etc.).

The key factor influencing the innovative development of the enterprise is the personnel, particularly their knowledge, loyalty to the company and innovative behavior without labor opportunism. A destructive change in work behavior can lead to devastating changes in other economic activities (Arman et al. 2019).

Opportunistic behavior is widespread in various fields like politics, economics, public life, and others. Special attention in the literature has recently been given to the behavior of employees in the course of the working process. Some Russian authors (Bodrov 2008, 2014; Belyaev et al. 2013, 2015, 2017; Ishchenko and Magsumov, 2019; Prokhorova et al., 2016; Dmitrieva et al., 2017; Trofimova et al., 2019; Girenko 2012; Pyatkova 2016) update the problems of research on labor opportunism and forms of its exhibition. Labor relations on a contractual basis imply the emergence of opportunistic behavior on the part of both the employer and the employee. Such kind of behavior causes a decrease in the level of labor productivity in the enterprise (Korableva et al., 2019; Sycheva et al., 2018; Luzina et al., 2019; Prodanova et al., 2019a,b; Ziyadin and Gulmira, 2015; Shrestha, 2019; Tadeu et al., 2019). It also blocks the innovative development of companies and increases transaction costs.

The main forms of opportunistic behavior in industrial enterprises are the opportunism of the employer and the opportunism of the employee.

This problem is covered in studies of foreign authors. The results of a number of studies (Laan et al. 2011; Wang et al. 2011; Belloc, 2012; Marjanovic et al. 2012; Bigliardi and Galati, 2016; Basterretxea et al., 2019; Guerrero et al. 2019; Rizki et al., 2019) show that labor opportunism affects the innovative development of enterprises. For example, scientists analyze the principle of cooperation in introducing innovations "through cooperation and overcoming the risk of opportunistic behavior" (Basterretxea et al., 2019) or its weakening due to the project unification (Laan et al., 2011). Jan-Erik Lane reviews opportunism as fraudulent behavior at the micro-level as one of its forms. Some scientists (Williamson, 1993; Rutten and Oerlemans, 2009) conducted a study of opportunistic behavior through the prism of trust meaning that labor opportunism is absent where the company has a high level of trust in the team. 


\section{ENTREPRENEURSHIP AND SUSTAINABILITY ISSUES}

ISSN 2345-0282 (online) http://jssidoi.org/jesi/

2020 Volume 7 Number 3 (March)

http://doi.org/10.9770/jesi.2020.7.3(51)

The most interesting is the view of Bengt-Ke Lundvall (2016). The author draws attention to the fact that opportunistic behavior leads to increased costs when introducing complex product innovations.

Labor opportunism should be understood as a form of selfish behavior of an employee pursuing personal gain as a response to a conflict of interests between economic agents in the course of labor activity.

\section{Methods}

Labor opportunism was identified among the significant factors blocking the innovative development of the enterprise.

The study of the energy industry enterprises of the Republic of Tatarstan included the following:

1. A questionnaire survey determining the level of labor opportunism in industrial enterprises of the energy sector. Respondents had to answer 20 questions in the questionnaire, which allowed determining the presence of various factors affecting labor opportunism of workers and blocking the innovative development of the enterprise. Employees and managers answered the same questions.

The questionnaire survey was conducted at four energy enterprises of the Republic of Tatarstan with more than 100 employees. Anonymous data collection was carried out from respondents who were ready to answer the questions presented in the questionnaire.

The survey of managers covered all levels of management (20\% - top management, $35 \%$ - middle management and $45 \%$ - lower management).

The collection and analysis of personal data based on the methods of grouping, classification, ranking and comparative analysis made it possible to systematize information and highlight the factors that determine the manifestations of labor opportunism and its forms, including those that block the innovative development of enterprises.

The data obtained is considered representative.

2. Assessment of the degree of influence of various factors on the level of labor opportunism of employees of energy enterprises based on correlation and regression analysis using the Gretl statistical package:

- at the first stage, a selection of factors most closely related to the effective attribute was carried out based on a matrix of paired correlation coefficients;

- at the next stage, the least-squares method was used to construct two models of the level of opportunism dependence on various factors. The first one is based on workers' $(\mathrm{n}=500)$ opinion and the second one is according to the managers' $(n=20)$ perspective. The level of workers' opportunism $(y)$ was considered to be a dependent variable;

- at the third stage, an analysis of the constructed models of the level of labor opportunism dependence on various factors was carried out and conclusions were made.

\section{Data Collection}

A secondary analysis of research data on opportunism and labor behavior that affects the innovative development of enterprises, the results of proprietary pilot sociological research and the results of a correlation-regression analysis of the degree of influence of various factors on the level of labor opportunism of energy enterprises employees formed the empirical basis of the study.

A sample selection of a pilot sociological survey conducted by the questionnaire survey method consisted of 500 people at the age of 18 to 65 years, out of which $26.2 \%$ were from 18 to 29 years old; $20.4 \%$ were $30-39$ years; 28.8\% were 40-49 years old; $18.4 \%$ were 50-59 years old, and 6.2\% were over 60 years old. Most of the respondents were men $(62.8 \%)$. In addition, 20 managers of different levels of government were interviewed. 


\section{ENTREPRENEURSHIP AND SUSTAINABILITY ISSUES}

ISSN 2345-0282 (online) http://jssidoi.org/jesi/

2020 Volume 7 Number 3 (March)

http://doi.org/10.9770/jesi.2020.7.3(51)

More than half of the managers (65\%) were in the age group of over 50 years old, 35\% of managers aged 40 to 49 years.

The results of employees' sociological study revealed factors that affected labor opportunism of workers and blocked the innovative development of the enterprise or (see Table 1).

Table 1. The presence of factors affecting labor opportunism of workers and blocking the innovative development of the enterprise (\%)

\begin{tabular}{|c|c|c|c|}
\hline No. & The presence of the factor in the organization & $\begin{array}{l}\text { According to } \\
\text { employees } \\
(n=500)\end{array}$ & $\begin{array}{l}\text { According to managers } \\
\qquad(n=20)\end{array}$ \\
\hline 1. & The company requires working on weekends and holidays & $12.2 \%$ & $10 \%$ \\
\hline 2. & The management often asks to stay late after work & $12.2 \%$ & $15 \%$ \\
\hline 3. & $\begin{array}{l}\text { Functional performance not included in official duties is } \\
\text { observed }\end{array}$ & $29.8 \%$ & $40 \%$ \\
\hline 4. & The staff is more often not satisfied with their work & $31 \%$ & $30 \%$ \\
\hline 5. & $\begin{array}{l}\text { The staff is more often not satisfied with the moral and } \\
\text { psychological climate in the team }\end{array}$ & $35 \%$ & $35 \%$ \\
\hline 6. & Dissatisfaction with wages & $72 \%$ & $90 \%$ \\
\hline 7. & Lack of correlation between the work done and the wages rate & $93 \%$ & $50 \%$ \\
\hline 8. & The wage does not match the amount of work performed & $73 \%$ & $20 \%$ \\
\hline 9. & Adverse teamwork between employees & $17.4 \%$ & $25 \%$ \\
\hline 10. & Adverse relationship between the supervisor and subordinates & $38 \%$ & $50 \%$ \\
\hline 11. & $\begin{array}{l}\text { Providing management with an interest in involving staff in the } \\
\text { development of recommendations for improving the activities of } \\
\text { the unit and innovative ideas for the development of the } \\
\text { enterprise }\end{array}$ & $9.2 \%$ & $30 \%$ \\
\hline 12. & Feedback on positive changes in the company & $8.2 \%$ & $30 \%$ \\
\hline 13. & Work overload & $42.4 \%$ & $60 \%$ \\
\hline 13. & The practice of double standards in the organization & $79 \%$ & $20 \%$ \\
\hline 14. & Underutilization of staff & $2.6 \%$ & $45 \%$ \\
\hline 15. & Lack of trust in the team & $82 \%$ & $90 \%$ \\
\hline
\end{tabular}

Source: The authors

Thus, according to the results of the study, 15 factors were identified that affect the opportunism of workers and block innovation in the enterprise.

The analysis of Table 1 shows that the most significant factors for the staff are the lack of correlation between the work done and the wages rate (93\%), lack of trust in the team (82\%) and the practice of double standards (79\%).

According to managers, the most significant factors affecting employee opportunism and blocking the innovative development of an enterprise are dissatisfaction with the wages rate (90\%) and lack of trust in the team (90\%).

Table 2. Types and forms of opportunistic behavior

\begin{tabular}{|c|c|c|c|}
\hline No. & Type (form) & According to employees & $\begin{array}{l}\text { According to } \\
\text { managers }\end{array}$ \\
\hline 1. & Employee workplace absence & - & - \\
\hline 2. & Heavy activity imitation & $24.2 \%$ & $40 \%$ \\
\hline 3. & Long approval of documents, projects, etc. & $22.6 \%$ & $50 \%$ \\
\hline 4. & Delaying accomplishment of work that can be done faster & $57 \%$ & $70 \%$ \\
\hline 5. & $\begin{array}{l}\text { Gratuitous use of employee personal contacts to solve } \\
\text { company problems }\end{array}$ & $38.4 \%$ & $25 \%$ \\
\hline
\end{tabular}

Source: The authors 
The data in Table 2 show that the most common form of opportunistic behavior is delaying the accomplishment of work that can be done faster, indicated by $57 \%$ of employees and by $70 \%$ of managers.

According to respondents, managers have the following types of opportunism:

- requiring the employees to perform functions not included in the range of official duties $-29.8 \%$;

- requiring to work on weekends and holidays $-12.2 \%$.

- gratuitous use of personal connections of an employee to solve company problems $-38.4 \%$.

\section{Data Analysis}

Correlation and regression analysis were performed in the framework of the current study in order to quantify the influence of the factors presented in Table 1 on the level of labor opportunism at enterprises of the energy sector. At the same time, due to the ease of interpretation, the following form of a linear model of multiple regression was chosen:

$y=a_{0}+a_{1} x_{1}+a_{2} x_{2}+\ldots+a_{15} x_{15}$,

where $y$ is the frequency of cases of opportunism in the organization (effective sign),

$x_{1}, x_{2}, \ldots, x_{15}-$ values of 15 factors presented in Table 1 ,

$a_{1}, a_{2}, \ldots, a_{15}$ - the parameters of the model equation obtained by the ordinary least squares (OLS) method.

At the first stage, factors were selected into the model on the basis of a matrix of paired correlation coefficients. Those were selected out of the $x_{1}, x_{2}, \ldots, x_{15}$ factors for which the correlation coefficient is the smallest among the other factors, and at the same time is the largest with the effective attribute $y$. This allowed selecting the most significant factors and eliminating multicollinearity, that is, the combined influence of factors on the result that distorts the results of the model. The following factors were selected in the model as a result of the analysis of the pair correlation coefficients matrix:

$x_{6}$ - degree of dissatisfaction with the wage rate;

$x_{7}$ - degree of correlation between the work done and the wage rate;

$x_{15}-$ degree of lack of trust in the team.

At the next stage, the following model was obtained (see Table 3) using the least-squares method. Five hundred observations were used $(n=500)$, the level of opportunism of workers $(y)$ was viewed as a dependent variable. 
Table 3. Model 1: Dependence of the level of opportunism on $x_{6}, x_{7}, x_{15}$ factors (according to employees)

\begin{tabular}{|l|l|l|l|l|}
\hline & Coefficient & Std. error & $t$-statistics & $P$-value \\
\hline$x_{6}$ & 0.432815 & 0.0826546 & 4.5863 & 0.00002 \\
\hline$x_{7}$ & 0.534671 & 0.0654372 & 4.2451 & 0.00001 \\
\hline$x_{15}$ & 0.456781 & 0.0789047 & 2.3710 & 0.00082 \\
\hline
\end{tabular}

\begin{tabular}{|l|l|l|l|l|}
\hline Average variable dependency & 0.435467 & Statistical deviation of variable dependency & 03565746 \\
\hline Sum of squared errors & 3.854373 & Statistical model error & 0.185465 \\
\hline R-squared & 0.865457 & Corrected R-squared & 0.835436 \\
\hline F $(3,497)$ & 2.734647 & P-value & $2.12 \mathrm{e}-39$ \\
\hline Logical credibility & 22.43543 & Akaike criterion & -36.36657 \\
\hline Schwartz criterion & -27.5434 & Hannan-Quinn criterion & -32.63654 \\
\hline
\end{tabular}

The analysis of the model quality shows that it is high-quality and reliable since the value of the R-square $=0.865$ exceeds the threshold value of 0.5 significantly. This means that the constructed regression model accounts for $86.5 \%$ of changes in the level of opportunism, and the remaining $13.5 \%$ is explained by the influence of other factors that are not included in the model.

The value of the P-value parameter turned out to be $2.12 \mathrm{e}-39$, which is significantly less than the threshold value of 0.05 . This means that the model is generally significant.

The "Standard error" parameter estimates sample standard deviations for each coefficient of the regression equation and standard error of the coefficients. In this model, the P-value of all regression coefficients was less than 0.05 , so those can be considered statistically significant. For the constructed model, the standard error is much lower than the regression coefficient $(\mathrm{R}$-squared $=0.865)$, which suggests that the model is also reliable according to this criterion.

In order to assess the impact of each identified factor on the level of labor opportunism of employees in the company, elasticity factors for each of them were calculated. As a result, it was revealed that with an increase in wages by $1 \%$, the level of labor opportunism of employees will decrease by $0.42 \%$. In case the increase in the number of workers who see the connection between the work done and the wages is $1 \%$, the labor opportunism level will decrease by $0.35 \%$. With an increase in the level of trust in the team by $1 \%$, the level of opportunism will decrease by $0.31 \%$.

As a result of the analysis, the regression equation of labor opportunism of employees was constructed based on the obtained regression coefficients, from the point of view of the workers themselves:

$$
y=0.432 x_{6}+0.534 x_{7}+0.456 x_{15}
$$

If the average values of the corresponding variables are placed in this regression equation, then an average quantitative estimate of the level of labor opportunism of employees is obtained:

$$
y=0.432 \cdot 0.39+0.534 \cdot 0.42+0.456 \cdot 0.32=0.483 \text {. }
$$


That means that from the point of view of the workers themselves, $48.3 \%$ of their work is opportunistic in nature, which blocks the innovative development of enterprises and the exhibition of the initiative.

A similar regression model of opportunism of workers was built on the basis of a survey of managers. Moreover, the following 4 significant factors were selected based on the matrix of pair correlation coefficients:

$x_{6}$ - the degree of dissatisfaction with the wage rate;

$x_{10}$ - the level of relationship between the leader and his subordinates;

$x_{13}$ - the level of work overload;

$x_{15}$ - the degree of lack of trust in the team.

The results of the second simulation are presented in Table 4 . Twenty observations were used $(n=20)$. The level of opportunism of workers (y) was viewed as a dependent variable.

Table 4. Model 2: Dependence of opportunism on $x_{6}, x_{10}, x_{13}, x_{15}$ factors (according to managers)

\begin{tabular}{|l|l|l|l|l|}
\hline & Coefficient & Std. error & $t$-statistics & $P$-value \\
\hline$x_{6}$ & 0.4984013 & 0.110475 & 4.4670 & 0.00035 \\
\hline$x_{10}$ & 0.3829410 & 0.039484 & 3.7401 & 0.00012 \\
\hline$x_{13}$ & 0.3294871 & 0.119349 & 2.5866 & 0.03739 \\
\hline$x_{15}$ & 0.4304724 & 0.135284 & 3.3848 & 0.00248 \\
\hline
\end{tabular}

\begin{tabular}{|c|c|c|c|}
\hline Average variable dependency & 0.543375 & Statistical deviation of variable dependency & 0.036747 \\
\hline R-squared & 0.954644 & Corrected R-squared & 0.935476 \\
\hline $\mathrm{F}(3,497)$ & 129.4245 & P-value & $1.18 \mathrm{e}-12$ \\
\hline Logical credibility & 22.47654 & Akaike criterion & -41.05437 \\
\hline Schwartz criterion & -33.3747 & Hannan-Quinn criterion & -37.26453 \\
\hline
\end{tabular}

An analysis of the model 2 quality showed that its reliability was 0.9546 , since the value of R-squared $=0.955$. That means that this regression model describes $95.5 \%$ of the changes in the level of opportunism and only $4.5 \%$ falls under the influence of other reasons not included in the model.

The P-value parameter equal to $1.18 \mathrm{e}-12$ turned out to be less than $5 \%$, which confirms the significance of the model as a whole.

The value of the Standard Error parameter turned out to be 0.06, which is lower than the regression coefficient (Rsquared $=0.955$ ); therefore, according to this criterion, the model is reliable.

The values of the elasticity coefficients according to this model indicate that with an increase in wages by $1 \%$, the level of labor opportunism of workers will decrease by $0.57 \%$. Further, with an increase in the level of relations between the manager and subordinates by $1 \%$, the opportunism level will decrease by $0.32 \%$ and with a decrease in the level of workload, it will decrease by $0.25 \%$. If the level of trust in the team is increased by $1 \%$, the opportunism level decreases by $0,43 \%$. 


\section{ENTREPRENEURSHIP AND SUSTAINABILITY ISSUES}

ISSN 2345-0282 (online) http://jssidoi.org/jesi/

2020 Volume 7 Number 3 (March)

http://doi.org/10.9770/jesi.2020.7.3(51)

Based on the regression coefficients obtained as a result of the analysis, the regression equation of labor opportunism of workers was constructed from the managers' point of view:

$$
y=0.498 x_{6}+0.383 x_{10}+0.329 x_{13}+0.43 x_{15} .
$$

By substituting the average values of the corresponding variables in this equation, the average quantitative assessment of the level of labor opportunism of employees of energy enterprises was calculated:

$$
y=0.498 \cdot 0.34+0.383 \cdot 0.32+0.329 \cdot 0.41+0.43 \cdot 0.32=0.564 \text {. }
$$

This means that, according to managers, $56.4 \%$ of the activities of employees of the energy sector industrial enterprises are opportunistic in nature. Its effect is the lack of initiative on the part of the staff to improve the company and its innovative development.

\section{Discussion}

Innovation can become a restrictive barrier to a destructive economy if an economic entity "can strengthen its comparative advantage based on innovation" (Arman et al., 2019, p. 75). At the same time, researchers note that "innovation and social change have a devastating effect on the world system" (Arman et al., 2019, p. 76). Accordingly, in response to changes and the inability to adapt to them, the opportunistic behavior of personnel may arise in the form of resistance to the introduction of innovations, suppression of ideas, etc.

The conducted analysis made it possible to identify the current level of labor opportunism of workers in the energy sector, which affects the innovative development of the enterprise. On average, it is $48.3 \%$ as estimated by the employees themselves and $56.4 \%$ as estimated by managers.

In the process of researching forms of opportunistic behavior within the energy sector enterprises, it was revealed that the most common form of it was to drag out time to complete work that could be done faster: $57 \%$ of employees and $70 \%$ of managers.

Among respondents, $40 \%$ of managers and $24.2 \%$ of employees believe that the company often imitates heavy activity.

In general, according to the results of the study, various factors affecting labor opportunism of workers are observed at enterprises in the energy sector.

The opinions of staff and managers differ significantly on the following factors that affect labor opportunism of workers and block the innovative development of the enterprise: lack of correlation between the work done and the wages: $93 \%$ of employees versus $50 \%$ of managers; wages do not correspond to the volume of work performed $-73 \%$ versus $20 \%$. Most of the employees surveyed (82\%) noted the organization's practice of double standards and only $20 \%$ of managers indicated this. The management team of the company (45\%) believes that employees are not overloaded with work, while employees themselves almost do not think so (2.6\%).

It should be noted that in the opinion of only $9.2 \%$ of employees, the management is interested in involving staff in the development of recommendations for improving the activities of the unit and innovative ideas for the development of the enterprise. Among the managers' answers, the value of this indicator is 3.26 times higher. 


\section{ENTREPRENEURSHIP AND SUSTAINABILITY ISSUES}

ISSN 2345-0282 (online) http://jssidoi.org/jesi/

2020 Volume 7 Number 3 (March)

http://doi.org/10.9770/jesi.2020.7.3(51)

Despite the differences in assessments of various factors of opportunism, both workers and managers agree that there are two factors significantly affecting the level of labor opportunism and blocking the innovative development of enterprises: dissatisfaction with the wage rates and lack of trust in the team (Konovalov et al., 2017; Sharafutdinov et al., 2017).

Williamson (1993) in his economic theory of transaction costs regarded trust as the absence of opportunistic behavior (Williamson, 1993).

A $1 \%$ reduction in dissatisfaction with wages will lower the level of opportunism of workers by an average of $0.42 \%$ according to the workers themselves and by $0.56 \%$ according to the managers. An increase in the level of trust in the team by $1 \%$ can reduce the level of opportunism by an average of $0.57 \%$ according to workers and by $0.43 \%$ according to managers. Therefore, it is recommended that priority be given to these two factors.

Thus, there is ambiguity and differences in the responses of respondents from the group of employees and the group of managers regarding some factors that affect labor opportunism and block the innovative development of enterprises.

\section{Conclusions}

The following conclusions can be drawn based on the results of the study. Those can become the basis for a program to minimize the influence of factors that determine labor opportunism and block innovative development of an enterprise:

- labor opportunism is a factor of blocking the innovative development of enterprises;

- it is impossible to completely eliminate opportunistic behavior in the process of labor activity due to the objective opposition of the economic interests of the employee and the employer.

According to the results of a sociological study of workers in energy enterprises in the Republic of Tatarstan, the hypotheses were confirmed that labor opportunism is present in any enterprise due to the different economic interests of the employee and the employer. The most significant factors that affect the level of labor opportunism and block innovative development of the enterprise were identified.

The hypothesis of various ideas on labor opportunism among workers and managers of energy industry enterprises has also found confirmation.

The hypothesis of the influence of the identified factors on the labor opportunism level and the innovative development of enterprises was confirmed by the results of correlation and regression analysis. It was based on calculations of the corresponding elasticity coefficients using the Gretl statistical package.

The managers are offered the following recommendations in order to level the factors of labor opportunism of workers that block the innovative development of the enterprise:

1. Review the content of job descriptions for their compliance with the actual work performed.

2. Develop objective criteria for assessing the quality of labor in the context of each position.

3. Revise the organizational system of communications in order to ensure that the staff receives access to the necessary information for quality work.

4. Establish regular feedback from staff, broadcast positive changes to the team and the corresponding role of employees.

5. Arrange a study of the working time. Determine the standards for the performance of a particular operation.

6. Develop recommendations on the involvement of personnel in the processes of continuous improvement of the company. 


\section{ENTREPRENEURSHIP AND SUSTAINABILITY ISSUES}

ISSN 2345-0282 (online) http://jssidoi.org/jesi/

2020 Volume 7 Number 3 (March)

http://doi.org/10.9770/jesi.2020.7.3(51)

7. Develop an action plan for team building and the formation of trusting relationships that contribute to the exhibition of the initiative on the part of the staff.

8. Constantly train employees in problem areas of knowledge.

9. Review communication channels for transparency of information.

10. Organize the collection of ideas and opinions from employees: how to improve their work to improve the efficiency of the company and its innovative development.

Prospective research can be aimed at developing a model for the formation of anti-opportunistic behavior that impedes blocking the enterprise innovative development due to the human factor.

\section{References}

Adams, B. (2019). The Far Reaching Impact of Transformative Curriculum. Journal Of Curriculum Studies Research, 1(1), 17-32. Retrieved from https://curriculumstudies.org/index.php/CS/article/view/8

Akhmetshin, E. M. (2017). The System of Internal Control as a Factor in the Integration of the Strategic and Innovation Dimensions of a Company's Development. Journal of Advanced Research in Law and Economics, 8(6), 1684-1692. https://doi:10.14505/jarle.v8.6(28).03

Anamova, R. R., \& Nartova, L. G. (2019). Geometric spatial ability as an element of cognitive learning process. Periodico Tche Quimica, 16(32), 542-550.

Arman A., Saefuddin A., Suardi Wekke I., Mas'ud A., \& Abbas B. (2019). Innovation and the Disruptive Economy: Recent Developments on the Social Change of the Socioeconomic Phenomenon. International Journal of Innovation, Creativity and Change, 7(5), 71-77.

Arvanitis, S., Sydow N., \& Woerter M. (2008). Is There any Impact of University-Industry Knowledge Transfer on Innovation and Productivity? An Empirical Analysis Based on Swiss Firm Data. Review of Industrial Organization, 32(2), 77-94.

Bae, Y., \& H. Chang. (2012). Efficiency and Effectiveness Between Open and Closed Innovation: Empirical Evidence in South Korean Manufacturers. Technology Analysis \& Strategic Management, 24(10), 967-980.

Basterretxea, I., Charterina, J. \& Landeta, J. (2019). Coopetition and innovation. Lessons from worker cooperatives in the Spanish machine tool industry. Journal of Business \& Industrial Marketing, 34(6), 1223-1235. https://doi.org/10.1108/JBIM-01-2018-0015

Bekebayeva, A. D., Nurbayev, Z. E., Nursultanova, L. N., Azmukhanova, A. M., \& Yerimbetova, K. M. (2019). Formation and development of women's non-governmental organisations in central Asia. Space and Culture, India, 6(5), 136-155. https:// doi.org/10.20896/saci.v6i5.480

Belloc F. (2012) Corporate governance and innovation: a survey. Journal of Economic Surveys, 26(5), 835-864.

Belyaev, V.I. (2015). Labor opportunism: the essence and forms of manifestation. Bulletin of Tomsk State University, 398, $169-177$.

Belyaev, V.I., \& Kuznetsova, O.V. (2017). Theory, methodology, practice of a systematic solution to the problems of labor opportunism in enterprises. Bulletin of Tomsk State University. Economy, 37, 69-84.

Belyaev, V.I., Kuznetsova, O.V., \& Pyatkova, O.N. (2015). Labor opportunism in enterprises: content, forms of manifestation and ways to overcome it. Economic Development of the Region: Management, Innovation, Training, 2, 49-55.

Belyaev, V.I., Kuznetsova, O.V., Pyatkova, O.N., \& Shikhaleva, N.Yu. (2013). The institutionalization of labor relations and the overcoming of opportunism of personnel in industrial enterprises. Bulletin of Tomsk State University. Economy, 3(23), 61-70.

Bernardi, A. (2019). The capability approach and organizational climate as tools to study occupational health and safety. Insights into Regional Development, 1(2), 155-169. https://doi.org/10.9770/ird.2019.1.2(6) 


\section{ENTREPRENEURSHIP AND SUSTAINABILITY ISSUES}

ISSN 2345-0282 (online) http://jssidoi.org/jesi/

2020 Volume 7 Number 3 (March)

http://doi.org/10.9770/jesi.2020.7.3(51)

Bigliardi B., \& Galati F. (2016). Which factors hinder the adoption of open innovation in SMEs? Technology Analysis \& Strategic Management, 28(8), 869-885, https:// doi.org/10.1080/09537325.2016.1180353

Bodrov, O.G. (2008). Economic freedom and labor opportunism of company employees. Economic Analysis: Theory and Practice, 17(122), 35-39.

Bodrov, O.G. (2014). Assessment of the causes of labor opportunism of staff. Finance and credit, 12(588), 41-51.

Bodrov, O.G., Valitov, Sh.M., \& Tufetulov, A.M. (2014). Analysis of labor opportunism of company employees. Bulletin of the Volgograd State Technical University, 4(131), 13-22.

Dmitrieva, I. S., Sharafutdinov, R. I., Gerasimov, V. O., \& Akhmetshin, E. M. (2017). Method evaluation of the human capital with its innovational potential consideration and perspectives of regional development: The example of the Republic of Tatarstan and Volga Federal District regions. Espacios, 38(40)

El Iysaouy, L.; El Idrissi, N. E.; Tvaronavičiené, M.; Lahbabi, M.; Oumnad, A. 2019. Towards energy efficiency: case of Morocco, Insights into Regional Development 1(3): 259-271. https://doi.org/10.9770/ird.2019.1.3(6)

Girenko, L.A. (2012). Labor opportunism in the enterprise: problems and solutions. Global scientific potential, 10(19), $144-145$.

Guerrero, M., Herrera, F., \& Urbano, D. (2019). Strategic Knowledge Management Within Subsidised Entrepreneurial University-Industry Partnerships. Management Decision, 57(12), 3280-3300. https://doi.org/10.1108/MD-10-2018-1126

Hou, B., Hong, J., Wang, H., \& Zhou, Ch. (2019). Academia-industry collaboration, government funding and innovation efficiency in Chinese industrial enterprises. Technology Analysis \& Strategic Management, 31(6), 692-706.

Ishchenko, O.V., \& Magsumov, T.A. (2019). Siberian Students' Material Situation in the early 20th century (based on Student Questionnaires). Bylye Gody, 51(1), 366-379.

Konovalov, V. B., Tikhonov, A. I., Fursov, V. A., Sogacheva, O. V., \& Pyanova, N. V. (2017). Marketing planning in industrial enterprises in the context of import substitution strategy. International Journal of Applied Business and Economic Research, 15(12), $171-182$.

Korableva, O., Durand, T., Kalimullina, O., \& Stepanova, I. (2019). Studying user satisfaction with the MOOC platform interfaces using the example of coursera and open education platforms. Paper presented at the ACM International Conference Proceeding Series, 26-30. https:// doi.org/10.1145/3322134.3322139

Krasikov, O.A., \& Roshchina, I.V. (2018). Opportunism and labor opportunism of workers: general and specific features, causes of manifestation. Bulletin of Tomsk State University. Economy, 42, 119-128.

Laan A., Voordijk H., \& Dewulf G. (2011). Reducing opportunistic behavior through a project alliance. International Journal of Managing Projects in Business, 4(4), 660-679.

Lane, J.-E. (2017). Opportunistic Behaviour. Applied Economics and Finance, 4(4), 1-16.

Lateef, A. O., Bin, M. S. H., \& Ademola, F. J. (2019). Performance assessment based on Intelligent power management for standalone PV system in remote area of Ibadan, Nigeria. Journal of Applied Engineering Science, 17(1), 52-60.

Lazzarotti V., Manzini R., Pizzurno E. (2012). Setting up Innovation Networks: The Case of a Small Company in the Calibration Industry. Asia Pacific Management Review, 17(3), 281-300.

Lundvall, Bengt-Eke. (2016). The Learning Economy and the Economics of Hope, Anthem Press, 406p.

Luzina, T. V., Dudareva, E. A., Akhmetshin, E. M., Prodanova, N. A., Berdova, Y. S., \& Emaletdinova, G. E. (2019). International legal format for trans regionalisation of trade and economic partnership within BRICS in global development. Space and Culture, India, 7(3), 76-85. https:// doi.org/10.20896/saci.v7i3.508

Magsumov, T.A. (2014). Main approaches to the study of historical and educational process. Bylye Gody, 34(4), $720-726$.

Magsumov, T.A. (2017). Family and school in Russia at the beginning of the 20th century: Attempts to bridge the gap. European Journal of Contemporary Education, 6(4), 837-846. https://doi:10.13187/ejced.2017.4.837 


\section{ENTREPRENEURSHIP AND SUSTAINABILITY ISSUES}

ISSN 2345-0282 (online) http://jssidoi.org/jesi/

2020 Volume 7 Number 3 (March)

http://doi.org/10.9770/jesi.2020.7.3(51)

Marjanovic S., Fry C., \& Chataway J. (2012). Crowdsourcing based business models: In search of evidence for innovation 2.0. Science and Public Policy, March 8, pp. 1-15.

Meissner, D., \& E. G. Carayannis. (2017). Value Generation from Industry-Science Linkages in Light of Targeted Open Innovation. Journal of Knowledge Management, 21(2): 295-307.

Omarova, A., Doszhan, R., Saparova, G., \& Zharaskyzy, G. (2018). Diversification of R and D results commercialization. Problems and Perspectives in Management, 16(4), 331-343. https:// doi.org/10.21511/ppm.16(4).2018.27

Pavlyshyn, L., Voronkova, O., Yakutina, M., \& Tesleva, E. (2019). Ethical problems concerning dialectic interaction of culture and civilization. Journal of Social Studies Education Research, 10(3), 236-248.

Prodani, R., Bushati, J., Andersons, A. 2019. An assessment of impact of information and communication technology in enterprizes of Korça region. Insights into Regional Development, 1(4), 333-342. https://doi.org/10.9770/ird.2019.1.4(4)

Prodanova, N. A., Plaskova, N. S., Dikikh, V. A., Sotnikova, L. V., Nikandrova, L. K., \& Skachko, G. A. (2019a). Techniques for assessing the investment attractiveness of a commercial organization based on classical methods of strategic economic analysis. International Journal of Economics and Business Administration, 7(4), 35-46.

Prodanova, N. A., Trofimova, L. B., Bashina, O. E., Kachkova, O. E., Ilienkova, N. D., \& Polyanskaya, T. A. (2019b). Approaches for obtaining audit evidence at fair value measurement. International Journal of Economics and Business Administration, 7(3), $279-292$.

Prokhorova, M. P., Prodanova, N. A., Reznichenko, S. M., Vasiliev, V. P., \& Kireev, V. S. (2016). Innovation performance and its influence on enterprise economic efficiency in the market. International Journal of Economics and Financial Issues, 6(8Special Issue), 7883.

Pyatkova, O.N. (2016). Research and diagnosis of social and labor relations in organizations in order to overcome the problems of staff resistance to the introduction of innovative changes. Business strategies, 10(30), 10-13.

Radicic D., Douglas D., Pugh G., \& Jackson I. (2019). Cooperation for innovation and its impact on technological and non-technological innovations: empirical evidence for European manufacturing SMEs. International Journal of Innovation Management, $23(05), 1950046$.

Rizki, Moch., Parashakti, D.R. \& Saragih, L. (2019). The Effect of Transformational Leadership and Organizational Culture Towards Employees' Innovative Behaviour and Performance. International Journal of Economics \& Business Administration, 7(1), $227-239$.

Ruff, E.V. (2014). Opportunistic behavior in the system of labor relations at production enterprises. Journal of Economic Theory, 4, 234237.

Ruff, E.V. (2018). The matrix of forms of opportunism of workers in the aerospace industry. Journal of Economic Theory, 15(1), 136-139.

Rutten, R. P. J. H., \& Oerlemans, L. A. G. (2009). Temporary inter-organisational collaboration as a driver of regional innovation: An evaluation. International Journal of Innovation and Regional Development, 1(3), 211- 234.

Saenko, N., Voronkova, O., Volk, M., \& Voroshilova, O. (2019). The social responsibility of a scientist: Philosophical aspect of contemporary discussions. Journal of Social Studies Education Research, 10(3), 332-345.

Sharafutdinov, R. I., Gerasimov, V. O., Yagudina, O. V., Dmitrieva, I. S., \& Pavlov, S. V. (2017). Research of human capital in view of labour potential of staff: National companies case study. Paper presented at the Proceedings of the 29th International Business Information Management Association Conference - Education Excellence and Innovation Management through Vision 2020: From Regional Development Sustainability to Global Economic Growth, 839-852.

Shatalova, T. N., Chebykina, M. V., Zhirnova, T. V., \& Bobkova, E. Y. (2015). Methodological problems in determining the basic features of the sample set controlling the activities of the enterprise. Mediterranean Journal of Social Sciences, 6(3S4), 261-268. https://doi.org/10.5901/mjss.2015.v6n3s4p261

Shrestha, M. (2019). Influences of gender and locale on teachers' job satisfaction. Research in Educational Policy and Management, 1(1), 17-32. Retrieved from https://repamjournal.org/index.php/REPAM/article/view/7 


\section{ENTREPRENEURSHIP AND SUSTAINABILITY ISSUES}

ISSN 2345-0282 (online) http://jssidoi.org/jesi/

2020 Volume 7 Number 3 (March)

http://doi.org/10.9770/jesi.2020.7.3(51)

Strunc, A. (2019). The Politics of Culture. Journal of Culture and Values in Education, 2(1), 71-80. http://cultureandvalues.org/index.php/JCV/article/view/26

Sycheva, I. N., Akhmetshin, E. M., Dunets, A. N., Svistula, I. A., Panteleeva, T. A., \& Potashova, I. Y. (2018). Labour relations in research of socio-economic systems. European Research Studies Journal, 21(4), 356-367.

Tadeu, P., Fernandez Batanero, J., \& Tarman, B. (2019). ICT in a Global World. Research in Social Sciences and Technology, 4(2), i-ii. Retrieved from https://ressat.org/index.php/ressat/article/view/431

Tarman, B., \& Dev, S. (2018). Editorial: Learning Transformation through Innovation and Sustainability in Educational Practices. Research in Social Sciences and Technology, 3(1), i-ii. Retrieved from http://ressat.org/index.php/ressat/article/view/363

Trofimova, L., Prodanova, N., Korshunova, L., Savina, N., Ulianova, N., Karpova, T., \& Shilova, L. (2019). Public sector entities' reporting and accounting information system. Journal of Advanced Research in Dynamical and Control Systems, 11(8 Special Issue), 416424.

Tvaronavičienė, M. 2017. Clusters, innovations and energy efficiency: if relantionship could be traced, Marketing and Management of Innovations 2: 382 - 391 http://doi.org/10.21272/mmi.2017.2-35

Voronkova, O. Y., Iakimova, L. A., Frolova, I. I., Shafranskaya, C. I., Kamolov, S. G., \& Prodanova, N. A. (2019). Sustainable development of territories based on the integrated use of industry, resource and environmental potential. International Journal of Economics and Business Administration, 7(2), 151-163.

Wang L., Hoi J., Yeung Y., \& Zhang M. (2011). The impact of trust and contract on innovation performance: The moderating role of environmental uncertainty. International Journal of Production Economics, 134, pp. 114-122

Williamson, O. (1993). Calculativeness, trust and economic organization. Journal of Law \& Economics, 86(1), $453-486$.

Yemelyanov, V. A., Yemelyanova, N. Y., Nedelkin, A. A., \& Zarudnaya, M. V. (2018). Neural network to diagnose lining condition. Paper presented at the IOP Conference Series: Materials Science and Engineering, 327(2) https:// doi.org/10.1088/1757-899X/327/2/022107

Zeibote, Z., Volkova, T., \& Todorov, K. (2019). The impact of globalization on regional development and competitiveness: cases of selected regions. Insights into Regional Development, 1(1), 33-47. https://doi.org/10.9770/ird.2019.1.1(3)

Ziyadin, S., \& Gulmira, Y. (2015). Prerequisites for development and diversification of production in industry. Economic Annals-XXI, 5-6, $37-40$.

Irina FROLOVA is the $\mathrm{PhD}$ (Sociology), Associate Professor, Deputy Director on scientific work Kazan Innovative University named after V.G. Timiryasov, Kazan, Russia. Research interests: entrepreneurship and regional development; innovation and small firms; small firm internationalization; sustainability.

ORCID ID: https://orcid.org/0000-0002-8707-6336

\section{Vladimir NOSOV}

Doctor of Economics, Associate Professor. K.G. Razumovsky Moscow State University of technologies and management, Moscow, Russia, Moscow. Academy of the Investigative Committee of the Russian Federation, Moscow, Russia

Research interests: risk management in the sectors of the national economy.

ORCID ID: https://orcid.org/0000-0001-6158-0924 


\section{ENTREPRENEURSHIP AND SUSTAINABILITY ISSUES}

ISSN 2345-0282 (online) http://jssidoi.org/jesi/

2020 Volume 7 Number 3 (March)

http://doi.org/10.9770/jesi.2020.7.3(51)

\section{Nadezhda ZAVYALOVA}

$\mathrm{Ph}$. D, associate professor of Entrepreneurship and logistics department of Plekhanov Russian University of Economics. Expert in applied business research and analysis; leading supervisor for students' scientific projects. Currently engaged in teaching methods and methodologies of research, project management, corporate IT systems.

Research interests: project management, digitalization of business processes, big data analysis.

ORCID ID: https://orcid.org/0000-0003-2939-4974

\section{Aleksei DOROFEEV}

Senior Lecturer, Department of propaedeutics of dental diseases of the Institute of Dentistry of Sechenov University. Currently engaged in teaching dentistry, as well as conducts research in the field of team management, corporate reporting.

Research interests: management in dentistry, internal control systems, corporate ethics

ORCID ID: https://orcid.org/0000-0002-0815-4472

\section{Tatiana VOROZHEYKINA}

Doctor of Economics, Professor of Accounting, Account Analysis and Audit Department, Financial University under the Government of the Russian Federation

Specialist in internal corporate control, improvement of business processes and practices

Research interests: internal corporate control, digital economy and technological innovations, labor economy

ORCID ID: $\underline{\text { https://orcid.org/0000-0001-7295-1372 }}$

\section{Lyudmila PETROVA}

$\mathrm{PhD}$ in Economics, associate Professor of the Department of management, business organization and innovation of the Altai state University. Research interests:processing industry, sustainable development of territories, innovative, technological and social entrepreneurship, organic production, human capital.

ORCID ID: https://orcid.org/0000-0002-5339-9567

Register for an ORCID ID:

https://orcid.org/register

Copyright (C) 2020 by author(s) and VsI Entrepreneurship and Sustainability Center

This work is licensed under the Creative Commons Attribution International License (CC BY).

http://creativecommons.org/licenses/by/4.0/

\section{cC) (†) Open Access}

